\title{
Bystander Position Taking in School Bullying: The Role of Positive Identity, Self-Efficacy, and Self-Determination
}

\author{
Sandra K. M. Tsang, ${ }^{1}$ Eadaoin K. P. Hui, ${ }^{2}$ and Bella C. M. Law ${ }^{1}$ \\ ${ }^{1}$ Department of Social Work and Social Administration, Faculty of Social Sciences, \\ The University of Hong Kong, Pokfulam, Hong Kong \\ ${ }^{2}$ Division of Learning Development and Diversity, Faculty of Education, Hong Kong
}

Received 15 November 2010; Revised 31 March 2011; Accepted 14 August 2011

Academic Editor: Joav Merrick

School bullying has become an explicit, burgeoning problem challenging the healthy development of children and adolescents in Hong Kong. Many bullying prevention and intervention programs focus on victims and bullies, with bystanders treated as either nonexistent or irrelevant. This paper asserts that bystanders actually play pivotal roles in deciding whether the bullying process and dynamics are benign or adversarial. Bystanders' own abilities and characteristics often influence how they respond to victims and bullies. "P.A.T.H.S. to Adulthood: A Jockey Club Youth Enhancement Scheme" (P.A.T.H.S. = Positive Adolescent Training through Holistic Social Programmes) is an evidence-based positive youth development program which shows that primary intervention programs have constructive impacts on junior secondary school students' beliefs and behavior. This paper asserts that intrapsychic qualities, namely identity, self-efficacy, and self-determination, greatly influence how bystanders react in school bullying situations. The paper also explains how classroom-based educational programs based on the P.A.T.H.S. model have been designed to help junior secondary school students strengthen these characteristics, so that they can be constructive bystanders when they encounter school bullying.

KEYWORDS: Bullying, bystander, positive youth development, positive identity, self-efficacy, selfdetermination 


\section{SCHOOL BULLYING}

School bullying is a form of aggressive behavior, characterized by deliberate, repeated, and harmful abuse of power against victims who cannot easily defend themselves [1,2]. School bullying takes different forms and is often categorized into four types: physical bullying, verbal bullying, social exclusion, and extortion [3, 4]. Physical bullying refers to overt physical aggression such as slapping, pushing, kicking, and spitting. Verbal bullying, which refers to overt verbal aggression, includes name calling, teasing, insulting, and threatening speech. Social exclusion refers to damaging a target's peer relationships or social standing; tactics can include spreading rumors, ignoring the victim's presence, threatening others not to play with the victim, or directing threatening or intimidating stares towards the victim. Extortion is asking for money or property. In recent years, advancements in information technology have made cyber bullying a new challenge because it is easy to commit but difficult to prosecute.

School bullying has detrimental effects on bullies and victims, as well as on bystanders. Such harm can range from physical, psychological to mental; from intrapersonal to interpersonal; and from short to long term $[2,5,6]$. Bullies are at risk of becoming increasingly short of compassion and concern for others; they eventually are desensitized to bullying, which then becomes part of their normal life [7]. They may indulge in the satisfaction of aggressive behavior instead of academic pursuits and thus are more likely to drop out of school and be involved in gangs, delinquent activities, and antisocial behaviors [2,5]. They might have increased difficulty in maintaining healthy intimate interpersonal relationships and become abusive spouses and parents [4, 8]. Over the long term, they are at increased risk of depression and suicide [9].

For victims, extensive effects-persisting to adulthood - are seen on emotional, mental, psychological, physical, social, and academic functioning [1, 6, 10,11]. Those who are bullied during childhood are more likely than nonvictims to report depression, trait anxiety, and social anxiety [12], social phobia [13], as well as low self-esteem, loneliness, and relationship dysfunction [14].

Bystanders, too, are impacted. Students who observe bullying report feeling helpless, uneasy, and distressed. They often harbor guilt for not having helped the victim, anger towards themselves and the bully, and fear of becoming targets themselves $[10,15]$. They may also feel insecure at school and become inattentive in class as their attention is directed toward avoidance of bullying [10]. These effects can also carry over into adulthood - inability to solve problems assertively, distorted views of personal responsibility, desensitization toward antisocial acts, and diffusion of boundaries on acceptable behavior [10].

School bullying is one of the top three misbehaviors in students, with frequency and severity increasing [6, 16, 17]. In Hong Kong, a 2004 study on secondary-school teachers' and students' perceptions of bullying found that more than $50 \%$ of the respondents had been involved in bullying, as bullies, victims, or bystanders [17]. In a 2008 study by the same group of researchers, $87 \%$ of respondents reported witnessing verbal bullying in the past 6 months, with 30\% of them having seen it more than 10 times. Also, $68 \%$ of the respondents had experienced physical bullying in the past half year, with $14 \%$ experiencing it more than 10 times [4]. This worrying trend demands immediate work on effective strategies for the amelioration and prevention of school bullying.

Of course, school bullying has attracted massive research, and there are plenty of programs for bullies and victims [18-22]. Unfortunately, even though it is obvious that school bullying typically occurs in social contexts, existing studies often assume a bully-victim (dyadic) rather than a bully-victim-bystander (triadic) perspective. Bystanders are often taken as mere "passers-by," "observers," or "onlookers," as if they are transparent and immobile. In fact, bystanders warrant research attention because, in the social contexts of school bullying [23, 24], all people present are inevitably engaged in interactions, being explicit or implicit. Bystanders, who witness the bullying as it develops, occurs, and ends, cannot possibly be inactive in the process - whether they act or refrain, they have already added energy to either the bully or the victim. Understanding bystanders is also important because (a) they typically outnumber the bullies and victims and (b) they experience intrapsychic struggles, which are amenable to adjustment through psychoeducation.

In view of these traits, and of the pressing need to combat school bullying, this paper will advocate for giving due attention to the important role of bystanders in the understanding and management of 
school bullying. While teachers, school staff, and parent/nonparent volunteers in schools can be influential bystanders in the school bullying process, this paper confines its discussion to peer bystanders.

\section{BYSTANDERS' POSITION TAKING AS A STRATEGIC INTERVENTION}

Peer bystanders, who are the biggest group in school bullying and who may choose to adopt a variety of roles in school bullying, can decisively influence the intensity and outcome of bullying by assuming different roles or positions in the bullying process [5, 25, 26]. Twemlow et al. [26] have identified several different bystander roles. Bully (aggressive) bystanders may sustain bullying by offering positive feedback, such as joining in or actively reinforcing through laughs or encouraging gestures. Victim (passive) bystanders might simply stand aside and keep silent while observing, which actually renders silent consent [24, 27, 28] and becomes part of the victimizing process. Avoidant bystanders might facilitate victimizing by denying personal responsibility. Abdicating bystanders might use scapegoating to shed responsibility. In contrast to these first four types, Altruistic bystanders might mobilize personal or social resources to help reduce or even stop bullying, for example, defending victims, taking sides with victims, informing and seeking help from adults, comforting victims, or trying to make bullies stop [24]. In many incidents, when peer bystanders intervene against bullying, it tends to stop quickly [29].

After acknowledging the pivotal function of peer bystanders in influencing the course of school bullying, and identifying the different positions of such bystanders, it is logical to ask whether bystanders can be helped to take up the altruistic position to reduce school bullying, and how this can be achieved. According to Twemlow et al. [26], bystanders are actually uncomfortable in nonaltruistic roles or are at least caught in the dilemma of choosing among the different roles. Therefore, they are motivated to seek effective ways out. This search (i.e., a bystander taking a position) is affected by various environmental factors. Physical environmental factors include classroom spaciousness and even home proximity to bullies and victims. Social environmental factors include the availability of parents, teachers, other adults, or peers for protection or role modeling of different attitudes and skills of coping. In addition, the bystander's physical characteristics, social and academic status [5], and even social skills [25, 30] are certainly variables that influence bystanders' position taking.

In addition to these extrapsychic factors, the intrapsychic qualities of the individual bystander (e.g., positive self-identity, self-efficacy, and self-determination) are even more important, according to psychoeducational and clinical literature on bystanders [10, 29, 31-33]. In a bystander's spontaneous position taking, these intrapsychic qualities are not only directly and immediately relevant; they are also the factors most amenable to the control of the bystander.

\section{POSITIVE IDENTITY, SELF-EFFICACY, AND SELF-DETERMINATION IN BYSTANDERS' POSITION TAKING}

\subsection{Positive Identity}

Identity is a constellation of personality characteristics and social styles through which one defines oneself and is recognized by others. The development of a clear and positive self-identity rests on building selfesteem, facilitating the exploration of and commitment to self-definition, and reducing inconsistencies in the self to enhance role formation and achievement [34]. This definition of positive identity gives three clues to how bystanders can be constructive helpers in school bullying. The first strategy is to enhance the bystander's positive self-esteem, which is highly correlated with prosocial behavior and positive well-being $[32,35]$. The second strategy is to engage the bystander in thinking through and working out responses to situations like bullying, and upholding such options. Finally, the bystander needs to see the gaps between their ideal, real, and perceived selves, seeking to sort out such gaps in order to achieve peace of mind. To activate such strategies, it has been effective to present the potential bystander with case scenarios for 
guided discussion with self-reflection on choice of responses. The evaluation findings of Project P.A.T.H.S. reveal that students participating in the program performed better than their counterparts in different areas of psychosocial competencies and strengths, including positive identity, self-efficacy, and self-determination [36-38]. They also have lower intention to engage in problem behavior and higher life satisfaction [37].

The social identity of peer bystanders (i.e., at school) can also explain why genuine, high self-esteem is important in encouraging students to take the positive side in bullying. Some studies suggest that students of low self-esteem may attempt to gain social status in school through bullying others [39-41]. On the other hand, Salmivalli et al. [27, page 3] found that defenders of the victim had the highest social status, suggesting that "a child's social approval (positive status) is connected with obedience to rules, with friendliness, and with prosocial interaction". The defenders' high social status might be gained by others' appreciation of courageous, victim-defending behavior. Genuine high self-esteem, which is positively correlated with prosocial tendencies, is therefore needed for such behavior, as defending victims puts bystanders at risk of becoming victims themselves [35].

\subsection{Self-Efficacy}

Bandura [42] defined self-efficacy as "beliefs in one's capabilities to organize and execute the courses of action required to produce given attainments." Self-efficacy plays a central role in "exercise of personal agency" and revolves around the idea that "unless people believe that they can produce desired effects by their actions, they have little incentive to act" [43, page 1206]. It functions as a multilevel and multifaceted set of beliefs that can include a global self-efficacy or self-efficacy regarding different domains of the self [44]. Self-efficacy has been shown in both Hong Kong [17] and overseas [31] studies to positively affect prosocial behaviors, including bullying defending behavior. Students high in social self-efficacy are likely to try to help victims in bullying situations, whereas students with low levels of self-efficacy are more reluctant to intervene and help, regardless of their level of empathic responsiveness [45]. Even if peer bystanders know how to intervene effectively, if they believe that they will be ineffective or that other bystanders are more competent, they will be less likely to take action against bullying [25].

\subsection{Self-Determination}

Self-determination is defined by Catalano et al. as "the ability to think for oneself, and to take action consistent with that thought" [46, page 19]. It refers to the competence in thinking for oneself and autonomy in choice making. People who are self-determined are able to make choices according to their own thinking and are less likely to submit to outside pressure.

Group norms and school culture often create pressure for certain behaviors. Bystanders' position taking in bullying is very much the result of peer pressure and the desire to be accepted by peers [33]. Students are more likely to join in bullying if their social network does the same thing. Besides group norms, school culture also contributes to the social pressure on bystanders. In environments where speaking up against injustice is clearly accepted and valued, the risk of social rejection for active bystanders is reduced, whereas in environments where bullies hold the power to determine acceptance or rejection, the risks of speaking up are greater [5]. If students are well equipped with self-determination, they are less likely to acquiesce to negative peer pressure and school culture and are more able to take the positive side when they witness bullying.

\section{PROJECT P.A.T.H.S.: A POSITIVE YOUTH DEVELOPMENT PROGRAM ENHANCING STUDENTS' SELF-EFFICACY, POSITIVE IDENTITY, AND SELF-DETERMINATION}

Most school-bullying intervention programs, both in western countries and in Hong Kong [47, 48], focus on providing social skills training for bullies and victims, increasing students' awareness of bullying, 
heightening their concern for victims, providing peer mediation programs to improve students' intervention behavior, and creating an antibullying school ethos by restructuring the school environment. However, overseas evaluation studies show that these programs do not clearly improve bullying or victimization in the schools, or that they are effective in one school but not in others [15, 47, 49]. In Hong Kong, few (if any) systematic studies on evaluating the bullying intervention programs have been done. The effectiveness of these programs is therefore unknown.

In view of the increasing seriousness of school bullying, Project P.A.T.H.S. - a positive youth development program in Hong Kong-includes bullying as a discussion topic in its extension phase [50]. To fill the literature gap [51], the P.A.T.H.S. curriculum (see the appendix) focuses on facilitating students to become prosocial helpful bystanders. The curriculum references literature on psychoeducational programs to enhance positive identity, self-efficacy, and self-determination, in combination with Salmivalli's recommendations [24] in the case of school bullying to offer (1) general awareness raising, (2) chances for self-reflection, and (3) possibilities to rehearse new behavior.

In Secondary 1 of the new curriculum, students are introduced to basic knowledge on bullying, including what it is and what its effects are, as well as dos and don'ts when facing bullying. Through understanding the effects of bullying, students can understand how bullying harms themselves and others, in order to keep from joining in. Teaching students dos and don'ts may also help them protect themselves when being bullied. The focus shifts to bystanders in Secondary 2 and Secondary 3, with four goals: to understand that peer bystanders play an important role in bullying and can alter the outcome of bullying; to learn to be a wise and sensible bystander in school bullying; to be a responsible bystander in cyberbullying; to learn to understand and accept the differences and constraints of others.

In addition to the new curriculum addressing bullying, the Project P.A.T.H.S. Tier 1 programs (original phase) - a universal positive youth development program for students in Secondary 1 to 3also help enhance participants' self-efficacy, positive identity, and self-determination, aside from other essential competencies in social bonding, emotional competence, and moral judgments. For example, in the units on self-efficacy, students are encouraged to recognize their successful experiences; to experience self-efficacy through enactive attainment; to be connected to ownership in goal setting, self-regulation, and self-efficacy in goal attainment; to manage their psychological selves in goal attainment. The units on positive identity help students to accept and appreciate themselves; to explore their ideal, actual, and ought selves; to enhance their feelings of mission. The units on self-determination focus on enhancing students' understanding of autonomy and their involvement/competence in goal setting and action planning, and on promoting students' problem-solving and decision-making skills in confronting risk-taking behaviors and undesirable peer influences.

The curricula in the original phase and in the extension phase work in a spiral manner that enhances students' self-efficacy, positive identity, and self-determination and repeatedly consolidates what they have learnt year by year. The cultivation of self-efficacy and positive identity, together with the knowledge of effective intervention skills, enables students to exercise their self-determination skills in making sensible decisions and taking prosocial stands against school bullying. One caveat is that the curriculum should be applied with a gender-sensitive perspective. Some studies [52] have found that boys may have higher dropout rates from programs that try to develop them into helpful bystanders, especially when conventional masculine role models and macho values (like those in Chinese families) prevail in society.

\section{CONCLUSION}

School bullying is a triadic social process, in which bystanders assume roles equal to, if not more important than, those of bullies and victims in steering the course and outcome of bullying. Fellow students, teachers and staff at school, and parents who interact with their children's lives at school are all bystanders, but this paper has focused on peer bystanders. Peer bystanders' position taking is influenced by many different physical, psychosocial, and intrapsychic factors. Of these, three intrapsychic attributes-positive identity, 
TABLE 1: Bullying units overview.

\begin{tabular}{|c|c|c|c|c|}
\hline & $\begin{array}{l}\text { Unit code/unit } \\
\text { Name }\end{array}$ & Construct & Unit aim & Learning targets \\
\hline \multirow{3}{*}{ Secondary 1} & $\begin{array}{l}\text { AB1.1 incidents } \\
\text { of bullying }\end{array}$ & $\begin{array}{l}\text { Behavioral } \\
\text { competence, } \\
\text { emotional } \\
\text { competence, } \\
\text { resilience }\end{array}$ & $\begin{array}{l}\text { To understand what is } \\
\text { meant by bullying and its } \\
\text { consequences, to avoid } \\
\text { being a bully or a victim }\end{array}$ & $\begin{array}{l}\text { (1) To understand the definition of bullying } \\
\text { (2) To investigate the behavioral and } \\
\text { emotional reactions of the bully, the victim, } \\
\text { and bystanders in bullying incidents, and } \\
\text { the consequences of bullying }\end{array}$ \\
\hline & $\begin{array}{l}\text { AB } 1.2 \text { behind } \\
\text { the mask of } \\
\text { bullying }\end{array}$ & $\begin{array}{l}\text { Emotional } \\
\text { competence, } \\
\text { behavioral } \\
\text { competence }\end{array}$ & $\begin{array}{l}\text { To understand the true } \\
\text { needs of the bullies and } \\
\text { identify proper approaches } \\
\text { to minimize bullying }\end{array}$ & $\begin{array}{l}\text { (1) To understand the reasons of bullying } \\
\text { and the mentality of the bullies } \\
\text { (2) To identify suitable approaches to fulfill } \\
\text { the underlying needs of the bullies in order } \\
\text { to reduce bullying }\end{array}$ \\
\hline & $\begin{array}{l}\text { AB1.3 a secret } \\
\text { book of } \\
\text { bullying } \\
\text { prevention }\end{array}$ & $\begin{array}{l}\text { Social } \\
\text { competence, } \\
\text { behavioral } \\
\text { competence }\end{array}$ & $\begin{array}{l}\text { To learn what should be } \\
\text { done in the face of bullying }\end{array}$ & $\begin{array}{l}\text { To learn dos and don'ts in the face of } \\
\text { bullying }\end{array}$ \\
\hline \multirow[t]{2}{*}{ Secondary 2} & $\begin{array}{l}\text { AB2.1 I can } \\
\text { make a } \\
\text { difference }\end{array}$ & $\begin{array}{l}\text { Moral } \\
\text { competence, } \\
\text { prosocial } \\
\text { norm }\end{array}$ & $\begin{array}{l}\text { To understand that } \\
\text { bystanders play an } \\
\text { important role in bullying }\end{array}$ & $\begin{array}{l}\text { (1) To understand that the "bystander } \\
\text { effect" has a significant impact on a } \\
\text { person's decisions and behavior } \\
\text { (2) To understand that the consequences of } \\
\text { a bullying incident vary with the attitudes } \\
\text { and resnonses of the bystanders }\end{array}$ \\
\hline & $\begin{array}{l}\text { AB2. } 2 \text { make a } \\
\text { smart move }\end{array}$ & $\begin{array}{l}\text { Moral } \\
\text { competence, } \\
\text { behavioral } \\
\text { competence }\end{array}$ & $\begin{array}{l}\text { To learn to be a wise and } \\
\text { responsible bystander }\end{array}$ & $\begin{array}{l}\text { (1) To understand the factors affecting the } \\
\text { attitudes and responses of bystanders to } \\
\text { bullying incidents } \\
\text { (2) To investigate how to stop school } \\
\text { bullying wisely }\end{array}$ \\
\hline \multirow[b]{2}{*}{ Secondary 3} & $\begin{array}{l}\text { AB3.1 online } \\
\text { buddies }\end{array}$ & $\begin{array}{l}\text { Moral } \\
\text { competence }\end{array}$ & $\begin{array}{l}\text { To learn to be a responsible } \\
\text { bystander in cyber bullying }\end{array}$ & $\begin{array}{l}\text { (1) To know the tremendous harm that } \\
\text { cyber-bullying can cause } \\
\text { (2) To investigate the proper attitude for } \\
\text { bystanders in cyber bullying incidents }\end{array}$ \\
\hline & AB3.2 alien? & $\begin{array}{l}\text { Social } \\
\text { competence }\end{array}$ & $\begin{array}{l}\text { To learn and practice the } \\
\text { motto "seek common } \\
\text { ground and respect } \\
\text { differences; seek harmony } \\
\text { but not uniformity" }\end{array}$ & $\begin{array}{l}\text { (1) To understand that everyone has his/her } \\
\text { own limitations and is different from others } \\
\text { (2) To learn to understand, tolerate, and } \\
\text { accept those who are different from us }\end{array}$ \\
\hline
\end{tabular}

self-efficacy, and self-determination — are particularly important direct and immediate variables under the direct control of the bystander. Based on psychoeducational principles with demonstrated effectiveness in Project P.A.T.H.S., a positive youth development program assisting students in their growth to adulthood, this paper is a useful addition to the field, filling the literature gap on how peer bystanders can play a key role in ameliorating school bullying.

\section{APPENDIX}

For more details see Table 1. 


\section{ACKNOWLEDGMENT}

The preparation for this paper and the Project P.A.T.H.S. were financially supported by The Hong Kong Jockey Club Charities Trust.

\section{REFERENCES}

[1] D. Olweus, Bullying at School: What We Know and What We Can Do, Basil Blackwell, Oxford, UK, 1993.

[2] K. Rigby, Bullying in Schools and What to Do about It, ACER Press, Camberwell, Australia, 2007.

[3] P. K. Smith and K. Ananiadou, "The nature of school bullying and the effectiveness of school-based interventions," Journal of Applied Psychoanalytic Studies, vol. 5, no. 2, pp. 189-209, 2003.

[4] D. S. W. Wong, D. P. P. Lok, T. Wing Lo, and S. K. Ma, "School bullying among Hong Kong Chinese primary schoolchildren," Youth and Society, vol. 40, no. 1, pp. 35-54, 2008.

[5] S. Davis and J. Davis, School Where Everyone Belongs: Practical Strategies for Reducing Bullying, Research Press, Champaign, Ill, USA, 2nd edition, 2007.

[6] J. W. Y. Ng and S. K. M. Tsang, "School bullying and the mental health of junior secondary school students in Hong Kong," Journal of School Violence, vol. 7, no. 2, pp. 3-21, 2008.

[7] D. S. W. Wong, Helping Pupils Away from Bullying, Centre for Restoration of Human Relationships, Hong Kong, 2002.

[8] M. J. Elinoff, S. M. Chafouleas, and K. A. Sassu, "Bullying: considerations for defining and intervening in school settings," Psychology in the Schools, vol. 41, no. 8, pp. 887-897, 2004.

[9] R. Kaltiala-Heino, M. Rimpelä, M. Marttunen, A. Rimpelä, and P. Rantanen, "Bullying, depression, and suicidal ideation in Finnish adolescents: school survey," British Medical Journal, vol. 319, no. 7206, pp. 348-351, 1999.

[10] M. R. Kohut, The Complete Guide to Understanding, Controlling, and Stopping Bullies \& Bullying: A Complete Guide for Teachers \& Parents, Atlantic, Ocala, Fla, USA, 2007.

[11] K. Rigby, "Peer victimisation at school and the health of secondary school students," British Journal of Educational Psychology, vol. 69, no. 1, pp. 95-104, 1999.

[12] D. A. Roth, M. E. Coles, and R. G. Heimberg, "The relationship between memories for childhood teasing and anxiety and depression in adulthood," Journal of Anxiety Disorders, vol. 16, no. 2, pp. 149-164, 2002.

[13] R. E. McCabe, M. M. Antony, L. J. Summerfeldt, A. Liss, and R. P. Swinson, "Preliminary examination of the relationship between anxiety disorders in adults and self-reported history of teasing or bullying experiences," Cognitive Behaviour Therapy, vol. 32, no. 4, pp. 187-193, 2003.

[14] M. Schäfer, S. Korn, P. K. Smith et al., "Lonely in the crowd: recollections of bullying," British Journal of Developmental Psychology, vol. 22, no. 3, pp. 379-394, 2004.

[15] K. S. Whitted and D. R. Dupper, "Best practices for preventing or reducing bullying in schools," Children and Schools, vol. 27, no. 3, pp. 167-174, 2005.

[16] D. O. B. Lam and A. W. H. Liu, "The path through bullying: a process model from the inside story of bullies in Hong Kong secondary schools," Child and Adolescent Social Work Journal, vol. 24, no. 1, pp. 53-75, 2007.

[17] D. S. W. Wong, "School bullying and tackling strategies in Hong Kong," International Journal of Offender Therapy and Comparative Criminology, vol. 48, no. 5, pp. 537-553, 2004.

[18] L. Chang, Y. F. K. Fung, and Y. Wang, Social Emotional Development of Schooling: Preventing School Bullying and Helping Social Withdrawn Children, The Chinese University Press, Hong Kong, 2004.

[19] E. M. Field, Bully Blocking: Six Secrets to Help Children Deal with Teasing and Bullying, Jessica Kingsley, Philadelphia, Pa, USA, 2007.

[20] A. L. C. Fung and J. L. P. Wong, Project C.A.R.E.: Children and Adolescents at Risk Education, Hong Kong Christian Service, Hong Kong, 2007.

[21] Hong Kong Children \& Youth Services, Peace Campaign, Hong Kong Children \& Youth Services, Hong Kong, 2002.

[22] S. W. Wong, Research and Countermeasures on Student Bullying: Life Education as the Direction, Arcadia Press, Hong Kong, 2003. 
[23] E. A. Barton, Bully Prevention: Tips and Strategies for School Leaders and Classroom Teachers, Corwin Press, Thousand Oaks, Calif, USA, 2006.

[24] C. Salmivalli, "Participant role approach to school bullying: implications for interventions," Journal of Adolescence, vol. 22, no. 4, pp. 453-459, 1999.

[25] A. Stueve, K. Dash, L. O'Donnell et al., "Rethinking the bystander role in school violence prevention," Health promotion practice, vol. 7, no. 1, pp. 117-124, 2006.

[26] S. W. Twemlow, P. Fonagy, and F. C. Sacco, "The role of the bystander in the social architecture of bullying and violence in schools and communities," Annals of the New York Academy of Sciences, vol. 1036, pp. 215-232, 2004.

[27] C. Salmivalli, K. Lagerspetz, K. Björkqvist, K. Österman, and A. Kaukiainen, "Bullying as a group process: participant roles and their relations to social status within the group," Aggressive Behavior, vol. 22, no. 1, pp. $1-15,1996$.

[28] D. Schwartz, K. A. Dodge, and J. D. Coie, “The emergence of chronic peer victimization in boys' play groups," Child development, vol. 64, no. 6, pp. 1755-1772, 1993.

[29] D. L. Hawkins, D. J. Pepler, and W. M. Craig, "Naturalistic observations of peer interventions in bullying," Social Development, vol. 10, no. 4, pp. 512-527, 2001.

[30] R. J. Hazler, Breaking the Cycle of Violence: Interventions for Bullying and Victimization, Taylor \& Francis, Washington, DC, USA, 1996.

[31] G. Gini, P. Albiero, B. Benelli, and G. Altoè, "Determinants of adolescents' active defending and passive bystanding behavior in bullying," Journal of Adolescence, vol. 31, no. 1, pp. 93-105, 2008.

[32] J. Lodge and E. Frydenberg, "The role of peer bystanders in school bullying: positive steps toward promoting peaceful schools," Theory into Practice, vol. 44, no. 4, pp. 329-336, 2005.

[33] A. B. Nickerson, D. Mele, and D. Princiotta, "Attachment and empathy as predictors of roles as defenders or outsiders in bullying interactions," Journal of School Psychology, vol. 46, no. 6, pp. 687-703, 2008.

[34] S. K. M. Tsang and F. Y. Y. Yip, "Positive identity as a positive youth development construct: conceptual bases and implications for curriculum development," in Positive Youth Development: Development of a Pioneering Program in a Chinese Context, D. T. L. Shek, H. K. Ma, and J. Merrick, Eds., pp. 227-235, Freund Publishing House, London, UK, 2007.

[35] C. Salmivalli, A. Kaukiainen, L. Kaistaniemi, and K. M. J. Lagerspetz, "Self-evaluated self-esteem, peerevaluated self-esteem, and defensive egotism as predictors of adolescents' participation in bullying situations," Personality and Social Psychology Bulletin, vol. 25, no. 10, pp. 1268-1278, 1999.

[36] D. T. L. Shek, "Effectiveness of the tier 1 program of project P.A.T.H.S.: findings based on the first 2 years of program implementation," TheScientificWorldJournal, vol. 9, pp. 539-547, 2009.

[37] D. T. L. Shek and R. C. F. Sun, "Effectiveness of the tier 1 program of project P.A.T.H.S.: findings based on three years of program implementation," TheScientificWorldJournal, vol. 10, pp. 1509-1519, 2010.

[38] D. T. L. Shek and C. M. S. Ma, "Impact of the Project P.A.T.H.S. in the junior secondary school years: individual growth curve analyses," TheScientificWorldJournal, vol. 11, pp. 253-266, 2011.

[39] W. M. Bukowski, "What does it mean to say that aggressive children are competent or incompetent?" MerrillPalmer Quarterly, vol. 49, no. 3, pp. 390-400, 2003.

[40] G. Gini, "Bullying as a social process: the role of group membership in students' perception of inter-group aggression at school," Journal of School Psychology, vol. 44, no. 1, pp. 51-65, 2006.

[41] J. Juvonen, S. Graham, and M. A. Schuster, "Bullying among young adolescents: the strong, the weak and the troubled," Pediatrics, vol. 112, no. 6, pp. 1231-1237, 2003.

[42] A. Bandura, Self-Efficacy: The Exercise of Control, WH Freeman, New York, NY, USA, 1997.

[43] A. Bandura, C. Barbaranelli, G. V. Caprara, and C. Pastorelli, "Multifaceted impact of self-efficacy beliefs on academic functioning," Child Development, vol. 67, no. 3, pp. 1206-1222, 1996.

[44] S. K. M. Tsang and E. K. P. Hui, "Self-efficacy as a positive youth development construct: conceptual bases and implications for curriculum development," in Positive Youth Development: Development of a Pioneering Program in a Chinese Context, D. T. L. Shek, H. K. Ma, and J. Merrick, Eds., pp. 201-209, Freund Publishing House, London, UK, 2007. 
[45] R. Schwarzer, C. Dunkel-Schetter, B. Weiner, and G. Woo, "Expectancies as mediators between recipient characteristics and social support intentions," in Self-Efficacy: Thought Control of Action, R. Schwarzer, Ed., pp. 65-90, Hemisphere Publishing, Washington, DC, USA, 1992.

[46] R. F. Catalano, M. L. Berglund, J. A. M. Ryan, H. S. Lonczak, and J. D. Hawkis, "Positive youth development in the United States: research findings on evaluations of positive youth development programs," Prevention \& Treatment, vol. 5, no. 1, article 15, 2002.

[47] E. Andreou, A. Vlachou, and E. Didaskalou, "The roles of self-efficacy, peer interactions and attitudes in bullyvictim incidents: implications for intervention policy-practices," School Psychology International, vol. 26, no. 5, pp. 545-562, 2005.

[48] D. S. W. Wong and S. S. T. Lee, "Strategies in tackling school bullying: a whole-school approach," in Working with Youth-at-Risk in Hong Kong, F. W. L. Lee, Ed., pp. 39-52, Hong Kong University Press, Hong Kong, 2005.

[49] R. C. Vreeman and A. E. Carroll, "A systematic review of school-based interventions to prevent bullying," Archives of Pediatrics and Adolescent Medicine, vol. 161, no. 1, pp. 78-88, 2007.

[50] D. T. L. Shek, H. K. Ma, and R. C. F. Sun, "Development of a new curriculum in a positive youth development program: the Project P.A.T.H.S. in Hong Kong," TheScientificWorldJournal. In press.

[51] A. G. Carney and K. W. Merrell, "Bullying in schools: perspectives on understanding and preventing international problem," School Psychology International, vol. 22, no. 3, pp. 364-382, 2001.

[52] H. Cowie, "Bystanding or standing by: gender issues in coping with bullying in English schools," Aggressive Behavior, vol. 26, no. 1, pp. 85-97, 2000.

\section{This article should be cited as follows:}

Sandra K. M. Tsang, Eadaoin K. P. Hui, and Bella C. M. Law, "Bystander Position Taking in School Bullying: The Role of Positive Identity, Self-Efficacy, and Self-Determination," TheScientificWorldJOURNAL, vol. 11, pp. 2278-2286, 2011. 